University of Northern lowa

UNI ScholarWorks

$10-2018$

\title{
Real-World Research: A Qualitative Study of Faculty Perceptions of the Library's Role in Service-Learning
}

Anne Marie Gruber

University of Northern lowa

Let us know how access to this document benefits you

Copyright (C2018 Johns Hopkins University Press. Posted with permission.

Follow this and additional works at: https://scholarworks.uni.edu/lib_facpub

Part of the Library and Information Science Commons

\section{Recommended Citation}

Gruber, Anne Marie, "Real-World Research: A Qualitative Study of Faculty Perceptions of the Library's Role in Service-Learning" (2018). Rod Library Faculty Publications. 10.

https://scholarworks.uni.edu/lib_facpub/10

This Article is brought to you for free and open access by the Rod Library at UNI ScholarWorks. It has been accepted for inclusion in Rod Library Faculty Publications by an authorized administrator of UNI ScholarWorks. For more information, please contact scholarworks@uni.edu. 


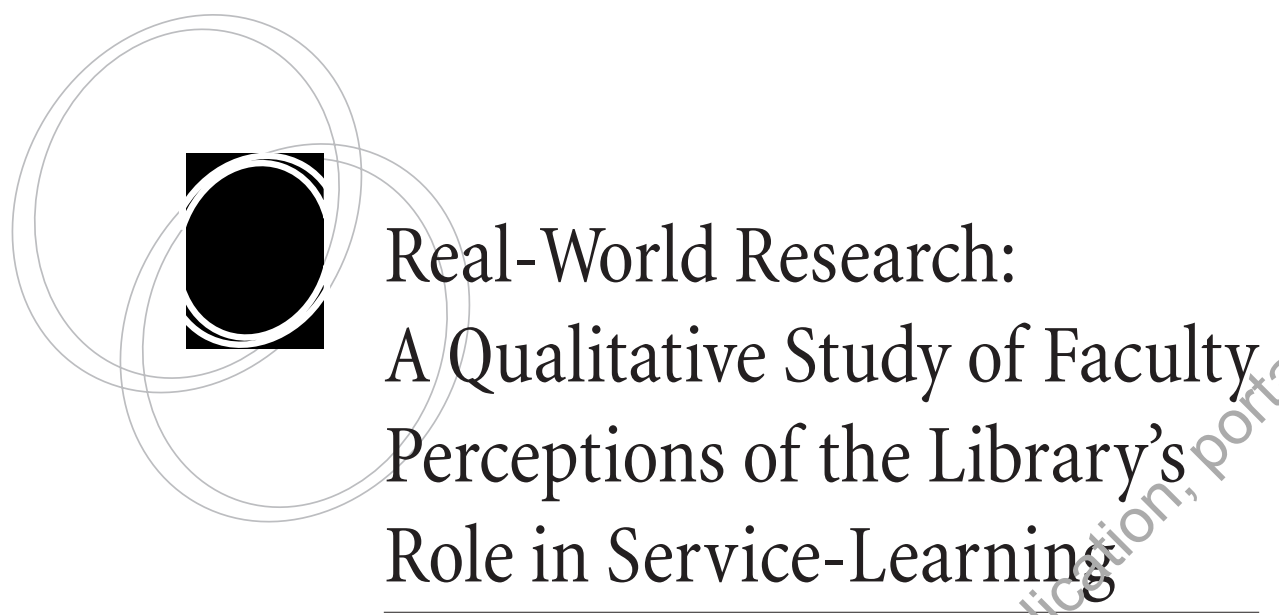

Anne Marie Gruber

abstract: Service-learning, a growing pedagogy in higher education, provides opportunities for students to contribute to communities and to reflect upon erofeiences ranging from direct service to advocacy. Librarians have an important but underutilized role in supporting service-learning as they contribute to institutional missions and the publepurposes of academia. However, there is a gap in the literature related to faculty perception@f information literacy instruction and skills related to service-learning. The researcher used sfoni-structured in-depth interviews, investigating these perceptions among 12 faculty across 10 disciplines. Findings support the role of library instruction in service-learning, with a focu on helping students engage with non-scholarly sources. Conclusions also suggest a need for additional marketing of library services to faculty who may have misconceptions about librarjang' scope of practice. The article also discusses implications relative to student success and ogoing articulation of academic library value.

\section{Introduction}

$\mathrm{N}$ afiohwide, many higher education institutions are increasing emphasis on service-learning within the college curriculum. It is considered a high-impact educational practice by accrediting agencies and by organizations such as Association of American Colleges and Universities (AAC\&U). Additionally, service-learning, and community engagement more broadly, are part of ongoing conversations about the public purposes of higher education. A widely accepted definition of service-learning comes from Robert Bringle and Julie Hatcher. They consider it a

course-based, credit-bearing educational experience in which students participate in an organized service activity that meets identified community needs and reflect on 
the service activity in such a way as to gain further understanding of course content, a broader appreciation of the discipline, and an enhanced sense of civic responsibility. ${ }^{1}$

Service-learning (SL) contributes to both students' development and the public good. It can help students develop skills that will translate to their chosen career fields and provide opportunities to improve broad-based abilities, such as writing, speaking, critical thinking, and intercultural competency. As part of an enriching educational environment and a pedagogical approach to learning "real-world" skills, SL can demonstrate added value for investments in education by families and the public, and can enable institutions to advocate for additional support.

The library has an important but often underutilized role to play in supporting (51). Librarians are well-positioned to help students prepare for service-learning opportunities by gathering evidence-based information about the communities in when such learning takes place. Collaborations between teaching faculty and librariansare key to

\section{Librarians are well-positioned to help students prepare for service- learning opportunities by gathering evidence-based information about the communities in which such learning takes place.}

this endeavor, and current information literacy (IL) theorieg and pedagogies support librarian collaborating with faculty. However, many faculty fail to seek libracy@upport for SL for a variety of reasge, often they simply may not have Considered how IL instruction or other library services can contribute to the learning objectives of SL projects. Effective partnerships can help students develop information-seeking and evalu-

ation skills. In addition, IL instruction can empower them to develop critical questions, create new information, investigate information processes and power structures, and engage with research as part of ant ongoing conversation. This study investigates faculty perceptions of the library's yoe in service-learning courses.

\section{Literature Review}

\section{Civic Engagement and Service-Learning}

Civic engagement and service-learning are not new concepts in higher education, but they have reggived increased attention of late. Service-learning is positively associated with studeptearning, retention, and success; as a high-impact practice, SL is one of several "en fiching educational experiences that can be life-changing" for students. ${ }^{2}$ Theresa Yeh Gound that SL opportunities, both cocurricular and course-integrated, enhanced lowincome, first-generation college students' "knowledge and learning in the classroom, enabled them to further develop academic skills, and linked them to new educational opportunities." ${ }^{3}$ While the benefits of service-learning are well-documented, a 2012 AAC\&U report indicated that "more evidence on civic learning is urgently needed," especially as related to impacts on student success and underserved students. ${ }^{4}$

Results of a survey conducted on behalf of AAC\&U showed that employers value graduates demonstrating skills that are often developed through service-learning. ${ }^{5}$ For 
example, they indicated interest in having new employees who can think critically and engage with the community. A significant majority of respondents suggested colleges should place more emphasis on critical thinking and analytical reasoning ( 82 percent), the ability to apply knowledge and skills to realworld settings (78 percent), and team...employers value graduates demonstrating skills that are often developed through service-learning. work or the ability to

collaborate with others in diverse settings (67 percent). In the same survey, 72 percent? of employers indicated more attention should be paid to teaching college students " Dhe location, organization, and evaluation of information from multiple sources." ${ }^{\prime 6}$

Graduates themselves find challenges keeping up with information ancoearning new information for personal and professional needs. A report by Projectinformation Literacy, a national study of how young adults find and use information during and after college, suggested that graduates are "specialized, employable, and relatively proficient information seekers" but also "reveal a failure of higher education to prepare lifelong learners who leave college experienced at framing and asking their own questions rather than responding to questions that had been assigned to then.."7

\section{Service-Learning and Information Literacy}

Christopher Sweet contends, "Information literacy is critical for getting students to understand the 'why' and 'how' that shouldgound all service-learning projects." ${ }^{8} \mathrm{He}$ adds, "Service learning, combined with intormation literacy, adds value to each and transforms both." ${ }^{\prime 9}$ Sweet also suggests best practices that include connecting these skill sets within higher education, giticulating SL within institutional and library goals, and focusing on information literacy's implications for students' contextual learning in service-learning courses. Thes Association of College and Research Libraries (ACRL) "Framework for Informaton Literacy for Higher Education"10 is a powerful tool that can inform collaborations supporting SL. It includes dispositions empowering learners to "see themselres as contributors to the information marketplace rather than only consumers of it"gind enabling them to "examine their own information privilege." 11

Authors cave called for more explicit inclusion of social justice concepts in the Framework Lisa Hinchliffe and Laura Saunders, for example, propose two additional Framerork concepts, including Information Social Justice. ${ }^{12}$ Heidi Jacobs suggests that idea(IIy "the dialogues we have surrounding information literacy instruction strive to fifu a balance in the daily and the visionary, the local and the global, the practices and the theories, the ideal and the possible." ${ }^{13}$ Jacobs draws upon James Elmborg's argument that "to be educators, librarians must focus less on information transfer and more on developing critical consciousness in students." ${ }^{14}$ Evidence-based SL may be one way to work toward this pedagogy.

Interest in the role of information literacy in service-learning has surged recently. Jennifer Nutefall and John Riddle provide basic overviews of ways to connect the two pedagogies. ${ }^{15}$ To date, the Colloquium on Libraries \& Service Learning has been held three times. First convened in 2014, ${ }^{16}$ it took place again in 2016 in conjunction with the bian- 
nual national conference sponsored by Campus Compact, "a national coalition of nearly 1,100 colleges and universities committed to the public purposes of higher education."17 The colloquium was held a third time in 2017 and will now be held annually. ${ }^{18}$ A 2016 book draws upon the colloquium and serves as the first monograph to gather research about information literacy and service-learning. ${ }^{19}$ Forthcoming publications focus on the library's role in service-learning as well as community engagement more broadly.

Most existing publications on information literacy for service-learning provide case studies rather than a research-based focus. Additionally, there is no current research about faculty perceptions of information literacy instruction as it relates specifically to service-learning. Much of the published research focused on faculty attitudes toward If relies on a survey methodology, which may provide a limited understanding of faculty experiences and perceptions. Although effective IL-SL collaborations already take place at many institutions, and there is strong potential for even more, the messige about library support may not yet have reached the SL community as a whoile. A review of programs from annual service-learning and community engagement conlerences shows little library representation, defined as zero to two sessions per year mentioning libraries in their titles or presenters' titles. ${ }^{20}$ One notable exception the this silo effect is a list of resources titled "The Role of Libraries in Engagement," compiled by librarian Sarah Goodwin Thiel for Campus Compact. ${ }^{21}$

\section{Faculty Perceptions of Information Literacy}

Several studies of faculty perceptions and attitudes toward information literacy have primarily focused on how faculty view students' skills in this area. A key publication regarding this topic categorized faculty perceptions into seven "conceptions" of IL.22 Stuart Boon, Bill Johnston, and Sheil a Webber studied English faculty, took a phenomenographic approach, and found that faculty view IL skills as vital for students in the discipline. ${ }^{23}$ Jonathan Cope ana Jesús Sanabria used a similar approach to investigate how academic disciplines ngay influence how faculty view IL. ${ }^{24}$ They found, however, that "institutional and curricular requirements and the needs of specific students overshadowed disciplinary training in the interviewees' responses." ${ }^{25}$ Christina Nilsen conducted a broader study using survey results from across Canada. She found that a small majority of faculty (54 percent) identified IL as very important for lower-level undergraduâtes. ${ }^{26}$ Some questions were library-centric, potentially lowering responses. For example, one asked, “How important are library research skills?" (emphasis added). Over (2) percent of respondents ranked lower-level undergraduates' IL skills as either fair Or poor. Other studies confirmed that faculty place importance on IL skills and genGrally perceive students' skills as lacking. ${ }^{27}$ A 2015 survey of faculty at the University of Northern Iowa in Cedar Falls supported this finding, albeit with disciplinary differences. Approximately 70 percent of arts and sciences faculty rated undergraduates' IL skills poor, while respondents in business and other professions agreed approximately 30 percent and 25 percent of the time, respectively. ${ }^{28}$

Patricia Vander Meer, Maria Perez-Stable, and Dianna Sachs found that some barriers to IL include lack of faculty awareness of library services, perceived lack of time in the curriculum, and the perception that IL concepts should be taught in other courses. ${ }^{29}$ Larry 
Hardesty's faculty culture model can offer some rationales for these barriers, including that faculty may value knowledge over teaching. ${ }^{30}$ Sharon Weiner found that faculty often teach IL concepts themselves without collaboration. ${ }^{31}$ However, Sophie Bury indicated that, among faculty at a large research university, 78.7 percent considered facultylibrarian collaboration optimal for teaching IL, while only 52.9 percent incorporated IL instruction into their courses. ${ }^{32}$ Of those who collaborated with librarians to provide IL instruction, 85 percent perceived some or substantial impact on student IL learning objectives. Laura Saunders determined, as previous researchers had, that "the onus is still on the librarians to initiate and sustain discussions with faculty" regarding IL. ${ }^{33}$ She found a general openness to collaboration with librarians but a need for librarians tg as one faculty respondent said, "aggressive in a good way" to share information about library services. Time and awareness barriers may be exacerbated with serviceearning units that require significant planning and class time.

\section{Faculty Perceptions of Library Support for Service-Learning}

While a growing body of literature relates to faculty perception of ${ }^{2} \mathrm{~L}^{34}$ as well as to the intersections between IL and service-learning, ${ }^{35}$ little has been written about faculty perceptions of the library as it relates to course-integrated serenice. This reflects the broader challenge of libraries being largely absent from comminty engagement literature. One article coauthored by a librarian and a sociology erofessor serves to "draw attention to the limited contribution of librarians to ES [ergaged scholarship]," which integrates academic knowledge with community-base friow-how. ${ }^{36}$ The authors' thorough literature review covering 20 years of engaged scholarship in a variety of disciplines found only a single article with a library focys

Results of the 2015 National Asessment of Service and Community Engagement (NASCE) as reported by Mathe Johnson and Donald Levy demonstrate that opportunities exist locally to assist grtudents in preparing for course-integrated service projects. ${ }^{37}$ The desire on the part of higher education legers nationwide to provide studients with impactful community grogagement experiences will only increase these opportunities. Incorperating SL into the curriculum is a major challenge for many faculty, and professional development and

\section{Librarians can play an important role by serving as a resource for faculty selecting nonprofit organizations and students preparing for service-learning projects.} 5 networking opportunities are needed to assist them. ${ }^{38}$ Librarians can play an important role by serving as a resource for faculty selecting nonprofit organizations and students preparing for service-learning projects.

The current study further addresses the lack of connection between librarianship and community engagement, filling current gaps in understanding the roles of academic libraries in service-learning. Exploring this topic from the perspective of teaching faculty in a variety of disciplines will bring to light ways academic libraries can leverage their existing resources and services to support campus needs and priorities. 


\section{Methodology}

This study explores how faculty perceive the role of IL skills and instruction in academic SL courses. There were two main objectives: to describe faculty expectations and perceptions of students' IL skills in academic SL courses, and to understand how faculty perceive IL instruction as part of such courses.

\section{Setting}

This study took place at University of Northern Iowa (UNI), a mid-sized public comprehensive university in Cedar Falls with a total enrollment of approximately 12,000 The institution has a strong history of service-learning. UNI is one of 361 institutions nationwide to be awarded the Carnegie Classification for Community Engagenrent, ${ }^{40}$ and it has been named to the President's National Community Service Honor Roll six times. ${ }^{41}$ The 2015 NASCE survey indicated 50 percent of UNI students engaged in community service and, of those, 20 percent participated as part of a course orother academic program..$^{42}$ There is strong administrative support, including funding, for increasing community engagement. The current UNI Strategic Plan incedes a goal to elevate community engagement, specifically to "create opportunitiefor students, faculty, and staff to build external relationships that enhance local aric global learning experiences and contribute to the cultural and economic vitality of the Cedar Valley and Iowa." ${ }^{43}$ Community engagement is the focus of the instity 'iion's Quality Initiative Project for upcoming Higher Learning Commission accreditation, and a team of university and community representatives recently created Civic Action Plan for the campus. An annual faculty Service-Learning Institute hat been offered since 2016 in collaboration with Iowa Campus Compact; in this selectiveopportunity, faculty learn about best practices and partner with a community orgenization to create projects for a course.

\section{Participants}

This Institutional Review, Board-approved study included UNI faculty from a broad range of disciplines, with primary emphasis in the social and behavioral sciences. The researcher used per posive sampling with a target sample size of 12 to 15 individuals, consistent with the recommendation from Greg Guest, Arwen Bunce, and Laura Johnson that data saturation can be reached with as few as six interview participants. ${ }^{44}$ Both pretenure ara tenured faculty across disciplines were included, as well as both full- and part-time faculty at any rank.

- CEligibility criteria include having one or more courses integrating service-learning ajithin one academic year prior to interview. This could include any experience meeting the Bringle and Hatcher definition of service-learning. ${ }^{45}$ Courses could include one or more such experiences, and community projects ranged among direct service (such as serving at a meal center for the homeless), indirect service (gathering extra produce from restaurants to bring to the meal center), and advocacy (contacting legislators to change laws about reclaiming extra food from restaurants).

The campus Office of Community Engagement provided a list of UNI servicelearning faculty. Due to the small size of the list, all such faculty were invited to participate in the study. However, a complete tally for all UNI service-learning faculty was 
not available because the university's list relies on faculty to self-report projects and likely underrepresents the true number of faculty who include service-learning in their courses. Nonetheless, it was a useful starting point. Recruitment took place via e-mail over several weeks. Additionally, announcements appeared in the university's electronic newsletter and in the library's newsletter. Twelve faculty were invited to participate, and all did so, representing 10 different disciplines and a variety of ranks, as listed in Table 1. Half the sample (six faculty) included information literacy instruction in one or more service-learning courses, and the remainder taught using service-learning but did not include IL instruction (also indicated in Table 1).

\section{Data Collection and Instrument}

For this exploratory study, the author conducted semi-structured in-depth interviews in late 2016, within two semesters of each participant's service-learning course or courses. Interviews were scheduled after both the information literacy session (iii)applicable) and the service-learning project were complete or nearly complete. The interview guides (available in Appendices A and B), with similar questions for eagh group, were domainorganized and sequential, focusing on the following four domains:

1. Faculty expectations/experiences with student osearch in SL

2. Faculty awareness of IL services (overall and for SL specifically)

3. Faculty expectations / responses to IL sessienl (only for faculty participants who scheduled an information literacy sesston)

4. Faculty perceptions of students' engagement/motivation.

Each participant received the appropriate guide prior to the service-learning project. The researcher tested a draft intervigit guide through a sample interview with a colleague and made small changes to improve the questions prior to data collection. Interviews lasted between 38 minutes and 1 hour 48 minutes, averaging 1 hour 10 minutes.

\section{Data Analysis}

Interviews were audio recorded with participant permission and transcribed by an external vendôt using institutional grant funds. Transcripts were coded using NVivo software to (ifientify trends. Using a process of applied thematic analysis ${ }^{46}$ the researcher determined themes using an inductive approach focusing on emerging ideas related to the four fopical domains described earlier. As themes emerged, the researcher developed a cedebook to define when to apply themes to relevant text. To ensure coding reliability, an external researcher coded two of the interview transcripts using the primary researcher's codebook. Initial intercoder agreement was determined to be 79 percent and 69 percent respectively, demonstrating a fair level of consistency in how codes were interpreted and providing a check on any potential researcher bias. Following the external coding review and discussion to rectify discrepancies, the researcher revised the codebook, combining some codes and defining several codes in more detail. The researcher recoded relevant transcript sections according to the revised codebook and analyzed coded results by theme to gain an overall sense of how participants described each topic, as well as to gauge any similarities and differences among participant responses. 
Table 1.

Summary of study participants

\begin{tabular}{|c|c|c|c|}
\hline $\begin{array}{l}\text { Participant } \\
\text { number }\end{array}$ & $\begin{array}{l}\text { Participant rank at } \\
\text { time of study }\end{array}$ & $\begin{array}{l}\text { Participant discipline } \\
\text { or department }\end{array}$ & $\begin{array}{l}\text { Information literacy } \\
\text { session }(\mathrm{s}) \text { in } \\
\text { service-learning } \\
\text { course? }(\mathrm{Y} / \mathrm{N})\end{array}$ \\
\hline 1 & Instructor & Teacher Education & $\mathrm{N}$ \\
\hline 2 & Assistant professor & Languages and Literatures & \\
\hline 3 & Instructor & Art & \\
\hline 4 & Associate professor & Leisure, Youth, and Human Services & $\mathrm{N}$ \\
\hline 5 & Instructor & Languages and Literatures & Y \\
\hline 6 & Professor & Business (Marketing) & Y \\
\hline 7 & Assistant professor & Philosophy and World Religiळs & $\mathrm{N}$ \\
\hline 8 & Associate professor & Leisure, Youth, and Humarervices & $\mathrm{N}$ \\
\hline 9 & Instructor & Social Work & $\begin{array}{l}\mathrm{N} \text { (LibGuide } \\
\text { only) }\end{array}$ \\
\hline 10 & Assistant professor & Family Serviced? & Y \\
\hline 11 & Professor & Physical Edrsation & $\mathrm{Y}$ \\
\hline 12 & Associate professor & Business (Management) & Y \\
\hline
\end{tabular}

\section{Results}

Several main themes emerged from participant responses, with only a few contradictions among participarts. Overall, faculty reported common concerns, such as lack of time and awareness then it comes to incorporating library services as well as perceived

In some cases, faculty lacked understefing that teaching abous non-scholarly sources falls within the scope of librarianship. deficiencies in student research skills. Specifically related to service-learning course and assignments, instructors placed greater emphasis on non-scholarly information for hands-on projects. In some cases, faculty lacked understanding that teaching about non-scholarly sources falls within the scope of librarianship. Some faculty reported that

"real-world" research enabled traditionally underprepared students to succeed. Each of the main themes that emerged upon data analysis is discussed in detail in the following sections. 


\section{Lack of Time and Awareness as Barriers to Library Use}

Barriers that Vander Meer, Perez-Stable, and Sachs identified still hinder student and faculty use of library resources and services when it comes to service-learning courses. ${ }^{47}$ Several participants, especially those previously unfamiliar with the researcher, admitted that they know less about library services than they would like and described a similar lack of awareness among students. Some expressed interest in finding ways to incorporate the library more often or more deeply into courses and assignments. One faculty member in the Family Services program explained: "I haven't done a good job of knowing what all is out there, like resources and services, or if the information just hasn't gotten to me in a way that ... I'm sure that there is more things [sic] that the library does or can do that I just am not aware of."

Library instruction and liaison services, in particular, are areas where taculty expressed a need for more information, as described by one participant in the Division of Leisure, Youth, and Human Services: "This whole idea that librarials are assigned to certain areas, I don't even know if I knew that until you told me 0 . The library is for people to go do research. It's not for me to lean on the people ho work there to help me teach my class."

However, this sentiment contradicts the experience of those faculty who had collaborated with librarians for service-learning courses Several instructors who had attended a prior presentation and simulation about the library's role in service-learning mentioned that it helped open their eyes to the potential for incorporating library instruction in their course: "In part because of the presentation ... I was like, 'Oh, my gosh, this is library resources, and library Pesearch days could be so beneficial."' Even among faculty aware of library services iricorporating them may look different in servicelearning courses. One faculty mepher from the Department of Philosophy and World Religions made an intentional cloice to exclude library instruction, afraid of upsetting the balance she had endeavored to create in her course between traditional classroom work and community serviee: "I was worried that if we had research-specific days, that it created an imbalance where they would be focused more on the inside the classroom stuff that we know they're already biaseg to do."

Some instructors indicated service-learning projects there so time-intensive that research assignmerts and library instruction would not fit into the coarse schedule. Faculty sometimes compensate for the lack of time by doing research themselves and providing information directly to students. One

Some instructors indicated service-learning projects were so time-intensive that research assignments and library instruction would not fit into the course schedule. from the Department of Languages and Literatures shared an example: "So I said okay, here's the percentage of Latinos in Iowa, here is Black Hawk County, here is the United States. Can you tell how many people speak Spanish in these different areas?" 


\section{Lack of Student Research Skills}

Not surprisingly, most faculty reported student research skills lacking; in fact, 11 of 12 participants mentioned student research skills in some way, and it was the most commonly discussed theme. Half the participants specifically listed source evaluation as particularly challenging for students, and moving away from traditional scholarly research, as often required in service-learning courses, only makes this concept more complex. One art faculty member described students' reaction during an SL-IL session and connected this to students' previous research experiences: "They were so excited about Control $F$ or any kind of methods of research ... I' $m$ kind of always surprised that they haven't done more of that when they were in high school." Another participan, from Philosophy and World Religions, described a sense of irony that student have easy access to information yet struggle to cope:

for as much access to technology the students have, just a misunderstanding or not even necessarily a misunderstanding, but ignorance of what is actually at their fingertips, and an inability to manage all that is available even if they do know how to access things that are available, which is why I see a clear benefit to incorporating [n ibrary instruction].

Some faculty, especially those who did not include a libraian in their course, report addressing source evaluation skills themselves throughopetures or class activities. One marketing faculty member shared: "I do spend abouf 20 minutes. I've got a little chart that I show, and I give examples, and I go throug10, and here I do follow the textbook closely. So, they give like eight or nine terms, and they do make a differentiation, let's say, between bias and purpose."

While faculty want students to develop information literacy skills, and several indicated their own efforts to target thesponcepts, many reported little or no departmentlevel plan to address IL skills. Ofterthis is due to strong expectations to cover particular topics within the subject area, soch as in physical education: "We haven't made room for this coherence across our cafeculum in terms of maybe critical thinking skills, writing, synthesis, those sorts of things because we're all focused on our little content area." In discussing future dirfetions for their service-learning courses, several faculty indicated they would increase the amount of library instruction, further emphasize informationrelated skills in their own teaching, or both. One representative comment came from a Languages ard Literatures participant: "I would have a longer check-in after the library session. IGipent about half a class when we were kind of evaluating sources. I would love to mavibe come back to the library and do that with a librarian." The same instructor wert on to share: "I always underestimate how much explicit instruction I need to do Gabout how to find a source, how to read the source."

\section{"Real-World" Non-Scholarly Information in Service-Learning}

Faculty from some disciplines, particularly those in business departments, mentioned valuing real-world information more than scholarly information at times for servicelearning projects. A marketing professor, when discussing students' legitimate use of blog sources for a project, indicated some selection criteria: "What we're going for is what can be used. So even if it is someone's biased opinion, if it seems to have worked 
for that person, it might work in this situation." A management faculty member discussed students' research process: "They Google something, and it comes up, and they go, 'Oh, this is what we're using.' You can then start to sometimes second-guess them and say, 'Well is this really appropriate for this particular question?' But lots of times it's good enough." Real-world sources such as government information and newspaper articles helped students engage with information in new ways, as reported by one faculty member from the Family Services program when describing students' reactions during an information literacy session: "I remember them saying, 'Wow! I didn't know that ... I never heard

Faculty from some disciplines, particularly those in business departments, mentioned valuing real-world information more than scholarly information at times for service-learning projectis. of a food desert.'”

The two members of the business faculty echoed each other when each discussing how students may struggle to understand that real-world soures, including experts in the community, are often acceptable and may even be mere important than scholarly sources for some purposes: “To figure out that the best source of information is probably your own boss and not some book, they don't get it," stated the management professor. A colleague in marketing commented, "It could come out of Google. Wikipedial at times is perfectly fine. And thisige-I mean, I go totally against evertything

The hands-on nature of the servicelearing projects seemed to provide opportunities for students to succeed who may have struggled with a more traditional scholarly assignment. they've been taught."

The hands-on nature of the service-learning projects seemed to provide opportunities for students to syceed who may have struggled with a more traditional scholarly assignment. In a sert timent echoed by several participants, a Languages and Literatures faculty membeirobserved:

I had one of my students ... she was a very weak academic student and one of those with a ceally low GPA and had to retake a lot of classes in college, but she was so at ease in the ommunity sessions, she went extra times. She didn't have to go. She just felt comfortable. She felt like she was doing something good. She liked the work, and she really excelled. She did very well in that, and if she hadn't done so well in that, she probably wouldn't have passed the class because she didn't do as well on the academic side.

Paralleling this, several faculty mentioned that an emphasis on real-world sources also provided an advantage to students who may have struggled with traditional research assignments, including this example from a participant in business:

It's funny because my " $\mathrm{C}^{\prime}$ students, they dive in. This is fun. They get to use any source they want? ... It's my " $\mathrm{A}$ " students that are the ones that are just like, "Are you sure 
about this?" I'll have people come up and say, "Do you need so many journal articles?" Because in the past, they've been told you have to have five journal articles and no later than 2014 and cited by so-and-so and use MLA . . . I still get that. "Do you have restrictions?" There's a website I found, it's a blog, but it's got some really good ideas. If it's got good ideas, do you think your manager could use it? Use the blog. I mean, we're going to break away from this whole entire structure that you've been involved with for the past 15 years, and so for some of the students that is a struggle.

\section{Combining Community Engagement with Research}

Some faculty participants, such as those in business, already require ample research if? service-learning projects. Others, such as one in Leisure, Youth, and Human Serviçes, indicated they wanted to incorporate research more: "I think I need to do more work about figuring out how to combine research and community work." Soree faculty thought about secondary research to increase rigor in their course. When asked about incorporating library instruction in the future, one faculty member in?hilosophy and World Religions responded: “One direction as a potential weakness of the class, and that might need to be addressed, is that students didn't do a Whole lot of academic work or output. Academic outcomes maybe is a good way to pget it for this class." Several faculty, including one in Languages and Literatures, expressed a desire to incorporate more real-world information into their courses: "Stuceftits I think are very interested in doing things related to current events, and we dom often have those kinds of projects embedded into our courses."

While some participants indicated an elegted importance of non-scholarly sources in service-learning projects and appeared to need support for incorporating research in this context, some faculty had not contis idered the scope of librarians to include helping students find and evaluate real-wend sources. Several faculty reported collaborating

... some faculty had notconsidered the scope of librarians to include helping students find and evaluate real-world sonices.

of that inpacking scholarship. However, I think that there's this bigger issue of being able to evaluate information as it comes in, and to me that is going to be a much more important skill than being able to dissect scholarship." The same faculty member, who Sonly recently began incorporating library instruction in her courses, indicated a past perception that teaching information literacy was her responsibility alone: "It never really occurred to me to lean on librarians or others ... I felt like the job was mine and not somebody else's."

\section{Faculty Role in Student Perceptions of Research}

Faculty take varied approaches when discussing research with students, often helping them realize they research constantly in their everyday lives and that research often 
involves more than finding a single correct answer. Some indicated students' levels may influence these understandings. The Languages and Literatures instructor described earlier, who teaches primarily a first-year composition and communication course, commented that it is "hard for students to understand is research is asking more questions. So, it's looking at something. It's asking more questions. Your typical freshman student might think research is finding an answer." An art instructor who also teaches many first-year students shares her perspective on research: "Research is different types of things; research doesn't always mean a paper, but experimenting with materials, like going and looking for just the right material and then taking it back to your studio ana trying different things out with it." A faculty member in the Department of Social Work took an evidence-based practice approach when describing her conceptualization of research, saying that in the field, students "need to be doing practice with pærposeful, planned supported practices with our client base. We don't just pull thing out of our back pocket."

Like several participants, the Social Work faculty member discussed the word research itself as problematic for students:

I think they hear research, and they do think it's steeped in the (ib rary with having to read article after article, and understanding, and looking at metholology, and all of those are a result of not really understanding what that really rogans. So that's why we want to move to away from using the word research and just feally embrace the evidence-based practices. And that comes in many different forms

One Languages and Literatures faculty finember talks with first-year students about real-world research they already do to help them broaden their definition: "I tell students, if you were looking at what tine a movie starts on a phone, do you consider that research? Are you looking up something? We do this more than we think."

The art instructor described her perception of how students think about research as something separate from their major or content area, indicating that students "automatically think, 'That's in the library, I do that in the library, I think about that in the library, and then I go back to he art building, okay now I'm thinking about art."' The same instructor went or to describe how the physical space of the library as distinct from a disciplinary or 'falssroom building may impact students' perceptions:

Even the distance that it takes to walk from the library back to the art building is eno igh time for their brain to make the switch. And I never really thought about it in (t) at particular way before, but I'm certain that that's what happened. And so, then they - 5 walk away from the library physically, and then that information also kind of leaves.

While many faculty incorporate reflection activities into service-learning projects, asking students to reflect on their research does not tend to be part of the project requirements. One business faculty member wishes to change this in the future: "I' $m$ going to have them start doing reflections on their research skills as well. So, I think that that'll make a big step forward." 


\section{Developing Social Issue Knowledge and Critical Thinking Skills}

Participants reported that library instruction helped students develop more nuanced understandings of social issues. The Languages and Literatures faculty member whose first-year students researched food insecurity—the lack of reliable access to affordable,

\section{Participants reported that library instruction helped students develop more nuanced understandings of social issues.}

nutritious food-in preparation for partnering with a regional food bank shared that the IL session

gave them a bigger picture. I think it gave them context to understand. In a complex issue like food insecurity, like poverty, they understand it's not just one thing, that there's a lot of moving pieces into this. Well maybe grtrey'd never considered ethnicity as a reason why or seen a graph that talked about ${ }^{\circ}$ Gender gap in wage earnings. They haven't seen that sort of thing, and so what it âs is I think it provides an understanding and takes away a lot of stereotypes.

The same instructor indicated that critical thinking was evident 'rstudents' responses to evidence-based data, especially data that challenged their assumptions: “Critical thinking, it's always ... probably the most difficult of our learniang outcomes to achieve and to assess, but I saw that enacted when students would fine something and kind of react to that information. They would be shocked or have prother question or wonder why that was true." This feedback supports the researche own experiences facilitating research and reflection in service-learning courses. Alisix faculty who incorporated library instruction in their course were pleased with the outcomes, though some still grapple with how to help students understand the infortance of research to community-based work.

\section{Limitations}

Limitations of this study iGolude the small sample size and single institution sample. While the results may ot be generalizable within the campus studied or to other institutions, this stud may shed some light on a nascent area of research in academic librarianship. Questions focused on information literacy rather than space, materials, and other library resources, so findings involve related topics. Some participants (8 of 12) were alfeady familiar with the researcher in some way, and 2 of the 12 had attended a preseration the researcher gave on the library's role in service-learning by the time of the study; these existing relationships indicate there was potential for participant bias.

\section{Conclusions and Recommendations}

Faculty awareness and time remain barriers to using library services, including information literacy instruction. While there are no quick fixes, several arguments for incorporating instruction that may advance the marketing of library services came from faculty themselves. Some faculty may see secondary research as a way to increase academic rigor in service-learning courses, and some desire support for more intentionally combining research and community work. Many departments need assistance with 
thinking about information literacy skills in a programmatic way for students within each major. These findings may lend credibility and relevance to librarians' discussions with faculty and administrators about the library's role in service-learning and more generally in the curriculum.

Librarians need to help faculty develop a stronger understanding that the scope of instruction librarians includes source evaluation and the use of free, non-scholarly information. That some faculty reported not considering librarians able to support students' use of non-scholarly sources has implications for both servicelearning and beyond, particularly considering current conversations about news and media literacy. Some libraries are already capitalizing on discussions of "fake news" to further publicize instructional

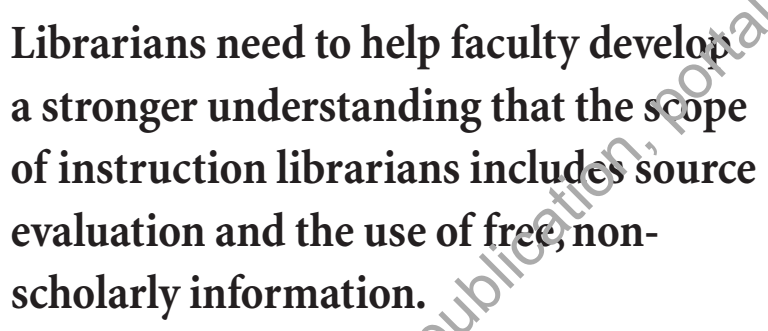
a stronger understanding that the scope of instruction librarians includes source evaluation and the use of free, nonscholarly information. services focused on source evaluation. Librarians should continue discussing students' inforifation skills with faculty and offering instructional services to help address the gaps

Faculty may need assistance incorporating research omponents into service-learning projects, so librarians should consider offering assistifice in the design of assignments in collaboration with both faculty and communitg partners. Librarians might also consider providing faculty with sample prompts or soliciting student reflections about the research process, in addition to the already ogmmon service-learning approach of having students reflect about the service experiznce.

Incorporating non-scholarly sotrices into service-learning projects can offer a more diverse group of students the opportunity to succeed in research assignments. Yeh's finding that service-learning especially benefited underrepresented students ${ }^{48} l i n k s$ well with the current study's firiting that underprepared students may excel at employing "real-world" sources more than their counterparts who are more comfortable using scholarly sources. Lilr rarians can lend their expertise in helping all students navigate and evaluate non scholarly sources, including experts in the community, through explicit instruction in spurce evaluation for service-learning courses as well as consultations supporting indifidual and small group projects. At the same time, engaging with secondary sources an help students understand that the issues addressed by community projects are cofrtplex, multifaceted, and not easy to solve. Incorporating effective IL instruction ir research and can help address student perceptions of research as negative, irrelevant to the "real world," or both. Librarians might consider teaching more information literacy sessions in classroom buildings, if space and technology allow, to address possible student perceptions of research as separate from academic pursuits in the disciplines.

Further research is needed to help librarians, faculty, and administrators improve and expand service-learning offerings on college campuses and support students' lifelong learning through civic engagement. While the proposed study focuses specifically on faculty perceptions, further studies may investigate student perceptions as well as any direct connection between IL instruction and student learning in the areas of critical think- 
ing and problem-solving in service-learning courses. Several study participants provided syllabi for service-learning courses, assignment instructions, and other artifacts, though these were not specifically requested. Content analysis of teaching materials as well as student work might answer a wide range of research questions that could aid librarians in understanding and supporting information needs for community engagement. Additionally, research is needed on library roles related to providing spaces and online archiving of artifacts (such as in institutional repositories) related to service-learning projects and community-engaged research.

Service-learning continues to expand in higher education as an effective student engagement and retention tool. It can also assist students' career, personal, and cognitize development. Shedding light on faculty perceptions of IL-SL connections may enabie librarians and faculty to better collaborate in creative ways that empower students to use research in solving deal-world

Information literacy is a natural connection with service-learning and can enrich the experiences of students, faculty, and nonprofit representatives... problems. This study can help faculty and dedministrators develop a richer understanding of aculty needs in implemerting service-learning and the library's role and value in supporting student learning. As academic librarians con-

tinue to provide leadership through innovative services, an increasing emphasis on civic engagement offers an important opportunitygodemonstrate the library's contribution to the development of students' lifelong skills. Information literacy is a natural connection with service-learning and can enrich hexperiences of students, faculty, and nonprofit representatives, but further study id needed to better understand the implications for various stakeholders. This study sheds light on faculty perceptions of the library's role in this process, providing idfeasfor creative faculty-librarian collaborations to empower students to conduct commurtity-engaged research, better understand their communities, and solve real-world problems. At the same time, the findings may help librarians think about additional ways to support institutional missions and articulate library value.

\section{Acknowledgments}

I am incebted to the staff and participants of the Institute for Research Design in Librarianship (IRDL) program, funded in part by the Institute of Museum and Library Services and'SAGE Publications. Without them, this research would not have been possible. Thank you to Kris Brancolini, Marie Kennedy, Michael Stephens, Greg Guest, Carol Raby, Jill Cornelio, and all the library faculty and staff at Loyola Marymount University in Los Angeles. Thank you to Amanda Woodward for serving as external coding reviewer and cheerleader, to Angie Cox for testing interview questions, and to Cara Stone, Lorelei Rutledge, and Adam Lisbon for editing assistance. A special word of appreciation also to Chris Cox, Jerilyn Marshall, Julianne Gassman, Kristina Kofoot, the Rod Library PreTenure Study Group, and Nate and Amelia Gruber. Finally, I would be remiss if I failed to mention my gratitude to my colleague Emily and to the 2016 IRDL participants, who are awesome in 509 ways. 
Anne Marie Gruber is an assistant professor and an instruction and liaison librarian at the University of Northern Iowa in Cedar Falls; she may be reached by e-mail at: anne.gruber@uni.edu.

\section{Appendix A}

\section{Interview Guide for Service-Learning Faculty with Information Literacy Session}

* = key questions within each domain

\section{Introduction}

Tell me a bit about the course in which you are including a service-learning (SL) project this [or last] semester. Course name? Student level?

Describe the SL project your students took part in this [or last] sernester.

Briefly describe any experiences you have had including SL inchle same or any other course prior to this one.

\section{Faculty Expectations/Experiences with Student Rosearch in SL (Domain 1)}

Think about SL projects you've had students com ellete for this or past courses. What sort of research did you ask them to do?

Describe the research assignment(s) you hod students complete.

*How well did students' level of researd s skills meet your expectations as far as service-learning is concerned?

What ways beyond research didyou encourage/ require students to prepare for the project?

Class discussion? Lecture? Readings? Reflections?

\section{Faculty Awareness of iL Services (Domain 2)}

Have you had adgrarian do any instruction in one of your classes before (servicelearning of hot)?

[If yes] What did you think of that experience?

*[Prior (3) my involvement with your course/the SL Institute], what thoughts do [did] (you have about library instruction for service-learning?

\section{Faculty Expectations/Responses to IL Session (Domain 3)}

*How would you describe the connection between library instruction and your students' success with SL projects?

Did the session contribute to your students meeting the course learning objectives for service-learning?

Are there other research-related components that could be included in the session to better meet the course objective?

What were [are] your expectations for librarians' instructional role in SL? 


\section{Faculty Perceptions of Student Engagement (Domain 4)}

Think about the library instruction session with a librarian. How did you see students engaging with information sources during the session?

How did they show interest and involvement within the session? Example?

Did you require students to do more with the information we gathered during the session? For an assignment? Reflection?

How did you use the information we had gathered during the course of the project?

How did you see or hear students refer to information sources during the course of the project?

What are some skill areas or tasks related to research that you see still needing improvement for students?

*Tell me about any changes you noticed in students' apparent motivation or ievel of engagement with the SL project over the course of the semester. How invested were they in the project?

Do you think research had anything to do with that?

\section{Closing}

Are there any other topics you'd like to discuss or commants you'd like to make? Any questions for me?

Thank you again for participating. If you'd like to oe notified of my research results, I'd be happy to let you know when I have resais published.

\section{Appendix B}

\section{Interview Guide for Service-Learning Faculty without Information Literacy Session}

* = key questions wition each domain

\section{Introduction}

Tell me a bit about the course in which you are including a service-learning project most recently. Semester? Course name? Student level?

Describe the SL project your students took part in this [or last] semester.

Briefly describe any experiences you have had including SL in the same or any other course prior to this one.

\section{Faculty Awareness of IL Services (Domain 1)}

Describe your experiences having a librarian work with any of your classes before (SL or not).

*What thoughts do you have about library instruction in relation to service-learning? 


\section{Faculty Expectations/Experiences with Student Research in SL (Domain 2)}

Think about SL projects you've had students complete for this or past courses. What sort of research did you ask them to do?

Describe the research assignment(s) you had students complete.

*How well did students' level of research skills meet your expectations as far as service-learning is concerned?

What ways beyond research did you encourage/require students to prepare for the project? Class discussion? Lecture? Readings? Reflections?

\section{Faculty Perceptions of Student Engagement (Domain 3)}

[If you required research] Did you require students to do more with the information they found? For an assignment? Reflection?

How did you see or hear students use the information they'd researcheaduring the project?

What are some skill areas or tasks related to research that you see till needing improvement for students?

*Tell me about any changes you noticed in students' apparent motivation or level of engagement with the SL project over the course of the semester. How invested were they in the project?

Do you think research had anything to do with that?

\section{Closing}

Are there any other topics you'd like t@eliscuss or comments you'd like to make? Any questions for me?

Thank you again for participating. If you'd like to be notified of my research results, I'd be happy to let you knorpwhen I have results published.

\section{Notes}

1. Robert G. Briogle and Julie A. Hatcher, "Implementing Service Learning in Higher Education, Jjournal of Higher Education 67, 2 (1996): 222, doi:10.2307/ 2943981.

2. NationalSurvey of Student Engagement, "Engagement Indicators \& High-Impact Prafffices," 2015, 1, http:/ / nsse.indiana.edu/pdf/EIs_and_HIPs_2015.pdf.

3. Treresa Ling Yeh, "Service-Learning and Persistence of Low-Income, First-Generation Ollege Students: An Exploratory Study," Michigan Journal of Community Service Learning 16, 2 (2010): 55, http:/ / hdl.handle.net/2027/ spo.3239521.0016.204.

•4. Ashley Finley, "A Brief Review of the Evidence on Civic Learning in Higher Education," American Association of Colleges \& Universities, 2012, 3, https: / / www.aacu.org/sites/ default/files/files/crucible/CivicOutcomesBrief.pdf.

5. Hart Research Associates, "It Takes More than a Major: Employer Priorities for College Learning and Student Success," 2013, https:/ / www.aacu.org/sites/default/files/files/ LEAP/2013_EmployerSurvey.pdf.

6. Ibid., 8.

7. Alison J. Head, “Staying Smart: How Today's Graduates Continue to Learn once They Complete College," Project Information Literacy, 2016, 5, http:/ / www.projectinfolit.org/ uploads/2/7/5/4/27541717/staying_smart_pil_1_5_2016b_fullreport.pdf. 
8. Christopher A. Sweet, "The Role of Information Literacy in Service Learning Courses: A Case Study and Best Practices," presentation at LOEX [Library Orientation Exchange] Annual Conference, Encore Virtual Session, May 31, 2012, http:/ / works.bepress.com/ christopher_sweet $/ 1 /$.

9. Ibid., slide 9 .

10. Association of College and Research Libraries, "Framework for Information Literacy for Higher Education," 2015, http:/ / www.ala.org/acrl/ sites/ala.org.acrl/files/content/ issues/infolit/Framework_ILHE.pdf.

11. Ibid., 6 .

12. Lisa Janicke Hinchliffe and Laura Saunders, "Framing New Frames: Expanding the Conceptual Space and Boundaries," presentation at LOEX Fall Focus Conference, November 2015, http: / / hdl.handle.net/2142/88407.

13. Heidi L. M. Jacobs, "Information Literacy and Reflective Pedagogical Praxis," Journal of . Academic Librarianship 34, 3 (2008): 258.

14. James Elmborg, "Critical Information Literacy: Implications for Instructional Proctice," Journal of Academic Librarianship 32, 2 (2006): 192, doi:10.1016/j.acalib.2005.12.604.

15. Jennifer Nutefall, “Why Service Learning Is Important to Librarians," OLX DOregon Library Association] Quarterly 17, 3 (2011): 16-21, doi:10.7710/1093-7374.1332; Jin S. Riddle, "Where's the Library in Service Learning? Models for Engaged Libráry instruction," Journal of Academic Librarianship 29, 2 (2003): 71-81, doi:10.1016/ s0099-1335(1)2)00424-x.

16. "Extending Our Reach: The Inaugural Colloquium on Librarie \& Service Learning," Colloquium on Libraries \& Service Learning, August 11, 20\%4, Santa Clara University, Santa Clara, CA, http: / / digitalcommons.lmu.edu/librades-and-service-learning/2014; "Libraries and the Public Purposes of Higher Education," Colloquium on Libraries \& Service Learning, March 20, 2016, Loyola Marymo@et University, Los Angeles, http:/ / digitalcommons.lmu.edu/libraries-and-service-(earning/2016; "Bridging Campus and Community: Libraries Transforming the Studght Experience through Service Learning," Colloquium on Libraries \& Service Learning, August 7-8, 2017, Santa Clara University, Santa Clara, CA, https: / / scholarcommerns.scu.edu/libraries-and-service-learning/2017/.

17. Campus Compact, "Campus Compget Overview," 2015, http:/ / compact.org/who-weare/.

18. "Bridging Campus and Comme nity," Colloquium on Libraries \& Service Learning.

19. Jennifer E. Nutefall, ed., Sercie Learning, Information Literacy, and Libraries (Santa Barbara, CA: Libraries Unlimited, (2016).

20. National Youth Leadership Council, "More Powerful Together," National Service Learning Conference, Washirgton, DC, April 8-11, 2015, http:/ / servicelearningconference. org/2015/dowojoads/04.01.15_Web_Listing.pdf;

National Youth Leadership Council, "Education. Ignite. Transform," 27th Annual National Sefvice-Learning Conference, Minneapolis, MN, March 30-April 2, 2016, http: / Servicelearningconference.org/2016/; National Youth Leadership Council, "Drve to Dream," 28th Annual National Service-Learning Conference, Anaheim, CA, Mrech 22-24, 2017, http: / / servicelearningconference.org/2017 / ; Campus Compact, Accelerating Change: Campus Compact Celebrates 30 Years of Educating Citizens and Building Communities," March 20-23, 2016, Boston, https:/ / compact.org/wp-content / uploads / 2017 / 11 / Campus-Compact-Conference-Agenda-FINAL.pdf.

21. Sarah Goodwin Thiel, "The Role of Libraries in Engagement Work," Campus Compact Knowledge Hub, http: / / compact.org / resource-posts / role-libraries-engagement-work/.

22. Christine Bruce, The Seven Faces of Information Literacy (Adelaide, Australia: Auslib Press, 1997).

23. Stuart Boon, Bill Johnston, and Sheila Webber, "A Phenomenographic Study of English Faculty's Conceptions of Information Literacy," Journal of Documentation 63, 2 (2007): 204-28, doi:10.1108/00220410710737187. 
24. Jonathan Cope and Jesús E. Sanabria, "Do We Speak the Same Language? A Study of Faculty Perceptions of Information Literacy," portal: Libraries and the Academy 14, 4 (2014): 475-501, doi:10.1353/pla.2014.0032.

25. Ibid., 486 .

26. Christina Nilsen, "Faculty Perceptions of Librarian-Led Information Literacy Instruction in Postsecondary Education," presentation, International Federation of Library Associations and Institutions General Conference and Assembly, Helsinki, Finland, June 1, 2012, https: / / www.ifla.org/ past-wlic/2012/105-nilsen-en.pdf.

27. Eleonora Dubicki, "Faculty Perceptions of Students' Information Literacy Skills Competencies," Journal of Information Literacy 7, 2 (2013): 97-125, doi:10.11645/7.2.1852; Sophie Bury, "Faculty Attitudes, Perceptions and Experiences of Information Literacy: A Study across Multiple Disciplines at York University, Canada," Journal of Information Literacy 5, 1 (2011), doi:10.11645/5.1.1513; Cope and Sanabria, "Do We Speak the Same Language?"

28. University of Northern Iowa, "ITHAKA University of Northern Iowa: Faculty Survey 2015," ITHAKA S+R, November 18, 2015.

29. Patricia Fravel Vander Meer, Maria A. Perez-Stable, and Dianna E. SachsOFraming a Strategy: Exploring Faculty Attitudes toward Library Instruction and Technology Preferences to Enhance Information Literacy," Reference \& User Ser iices Quarterly 52, 2 (2012): 109-22, https:/ /journals.ala.org/index.php/rusq/articke/_iewFile/3856/4267.

30. Larry Hardesty, "Faculty Culture and Bibliographic Instruction: An Exploratory Analysis," Library Trends 44, 2 (1996): 339-67, http:/ / hdl.handle.net /242/ 8028.

31. Sharon A. Weiner, "Who Teaches Information LiteracyGompetencies? Report of a Study of Faculty," College Teaching 62, 1 (2014): 5-12, doi:10.1080/87567555.2013.803949.

32. Bury, "Faculty Attitudes, Perceptions and Experien ces of Information Literacy."

33. Laura Saunders, "Faculty Perspectives on Inforrnation Literacy as a Student Learning Outcome," Journal of Academic Liggrianship 38, 4 (2012): 232, doi:10.1016/j. acalib.2012.06.001.

34. Cope and Sanabria, "Do We Speak thes Same Language?"; Dubicki, "Faculty Perceptions of Students' Information Literacy SRill's Competencies"; Bury, "Faculty Attitudes, Perceptions and Experiences of Informationiriteracy."

35. National Youth Leadership Shuncil, "Extending Our Reach"; National Youth Leadership Council, "Education. Ignite. Transform"; National Youth Leadership Council, "Dare to Dream"; Nutefall, Service Learning, Information Literacy, and Libraries; Sweet, "The Role of Information Literacy in Service Learning Courses."

36. Nicholas J. Rowland and Jeffrey A. Knapp, "Engaged Scholarship and Embedded Librarianship J Journal of Higher Education Outreach and Engagement 19, 2 (2015): 15, http: / / openjournals.libs.uga.edu/index.php/jheoe/article/view/1432.

37. Mather fohnson and Donald Levy, "2015 National Assessment of Service and Community Engagement," Siena College Research Institute, June 11, 2015.

38. Julianne Gassman, personal communication, December 9, 2015.

39. National Center for Education Statistics, "University of Northern Iowa Enrollment," 2016, https: / / nces.ed.gov/globallocator/col_info_popup.asp?ID=154095.

40. Swearer Center, Brown University, "Carnegie Community Engagement Classification," 2016, https: / / www.brown.edu/academics / college / swearer/carnegie-communityengagement-classification.

41. University of Northern Iowa, "UNI [University of Northern Iowa] Receives Community Engagement Classification from the Carnegie Foundation," January 7, 2015, https: / / uni. edu/newsroom/ uni-receives-community-engagement-classification-from-the-carnegiefoundation.

42. Johnson and Levy, "2015 National Assessment of Service and Community Engagement."

43. University of Northern Iowa, “Vision, Mission, and Strategic Plan 2017-2022," September 23, 2016, https: / / president.uni.edu / sites / default / files /UNI_Strategic_Plan_2017-2022_ FINAL.pdf, 3. 
45. Greg Guest, Arwen Bunce, and Laura Johnson, "How Many Interviews Are Enough? An Experiment with Data Saturation and Variability," Field Methods 18, 1 (2006): 59-82, doi:10.1177/1525822X05279903.

46. Bringle and Hatcher, “Implementing Service Learning in Higher Education," 222.

47. Greg Guest, Kathleen M. MacQueen, and Emily E. Namey, Applied Thematic Analysis (Los Angeles: SAGE, 2012).

48. Vander Meer, Perez-Stable, and Sachs, "Framing a Strategy."

49. Yeh, "Service-Learning and Persistence of Low-Income, First-Generation College Students." 